\title{
REGIONALNE ZRÓŻNICOWANIE FINANSOWANIA I EFEKTYWNOŚCI AKTYWNEJ POLITYKI RYNKU PRACY W POLSCE
}

\begin{abstract}
Streszczenie
Ewolucja w podejściu do realizowania polityki rynku pracy w Polsce i rosnące w związku z nią nakłady na aktywne programy rynku pracy rozpoczęły publiczną dyskusję nad ich efektywnością i celowością finansowania. Dlatego celem niniejszego opracowania jest przestrzenna analiza efektywności instrumentów stosowanych w ramach aktywnej polityki rynku pracy oraz poziomu i struktury środków z Funduszu Pracy przeznaczonych na ich finansowanie.

Analizę efektywności podejmowanych działań aktywizujących przeprowadzono za pomoca mierników efektywności zatrudnieniowej i kosztowej stosowanych przez publiczne służby zatrudnienia. Z kolei analiza wydatków została oparta na wtórnej analizie dostępnych danych statystycznych. W ujęciu regionalnym wskaźniki efektywności aktywnych form zatrudnienia potwierdzają niejednolity stopień rozwoju i niejednorodną sytuację na regionalnych rynkach pracy. Bowiem najbardziej efektywnie wydatkowane są środki publiczne w regionach silnych gospodarczo, o stabilnej sytuacji na rynku pracy i wyższej atrakcyjności inwestycyjnej.
\end{abstract}

Słowa kluczowe: polityka rynku pracy, Fundusz Pracy, aktywne instrumenty rynku pracy, efektywność

\section{REGIONAL DISPARITIES IN EFFECTIVENESS AND FUNDING OF ACTIVE LABOUR MARKET POLICY IN POLAND}

\section{Summary}

The evolution of the approach to labour market policy in Poland, as well as increasing expenditures on active labour market programmes, have initiated a public debate on the effectiveness and purposefulness of financing Active Labour Market Policies (ALMP). Therefore, the aim of this paper is to assess the regional effectiveness of selected instruments of labour market policy undertaken previously and an analysis of the levels and structure of the Labour Fund resources dedicated to funding these instruments.

The efficiency of activating methods is assessed with the use of employment and cost measures. Meanwhile, the expenditure analysis is based on available statistical data. The analysis of selected regional active labour market indicators has confirmed the inequalities between Poland's regional labour markets. The allocation of public funds was the most effective in well-developed regions with stable labour market conditions and high investment attractiveness.

Key words: labour market policy, Labour Fund, active instruments of labour market, efficiency

${ }^{1}$ Mgr Marlena Cicha-Nazarczuk - Wydział Nauk Ekonomicznych, Uniwersytet Warmińsko-Mazurskiw Olsztynie; e-mail: marlenacicha@wp.pl. 


\section{Wstęp}

Rynek pracy nie jest kategoria jednorodna. Jego zróżnicowanie w dużej mierze wynika ze specyfiki regionu, jego struktury, a przede wszystkim poziomu rozwoju. Współczesne bezrobocie, zatrudnienie czy rynek pracy są istotnie zróżnicowane przestrzennie. Przekonanie to wypływa z teorii rozwoju regionalnego [Nazarczuk, 2013, s. 15-69]. Podziały zachodzące na rynku pracy są jego cechą immanentna, a ich źródło tkwi między innymi w: podziale administracyjnym, relacji między popytem a podaża pracy i organizacji rynku pracy [Organiściak-Krzykowska, 2005, s. 81]. Wiąże się również z czynnikami historycznymi, kulturowymi czy geograficznymi [Jeran, 2011, s. 15]. Jednak należy mieć na uwadze fakt, iż wspomniane zróżnicowanie przestrzenne polskiego rynku pracy dotyczy nie tylko bieżącej sytuacji, ale i utrwalenia się pewnych niekorzystnych tendencji w długim okresie. Pojawiły się bowiem obszary, które od wielu lat borykają się np. z problemem zbilansowania popytu na pracę z podażą pracy [Witkowski, 2007, s. 12].

Poprawa efektywności funkcjonowania wspomnianego rynku, rozwiązywanie występujących na nim problemów strukturalnych i w konsekwencji łagodzenie skutków bezrobocia rodzi potrzebę interwencji państwa w tym zakresie. Choć w literaturze przedmiotu coraz częściej pojawia się pytanie, czy interwencja ta jest rzeczywiście potrzebna, a jeśli tak, to w jaki sposób należy skutecznie na ten rynek oddziaływać. Zdaniem Wiśniewskiego [Efektywność polityki..., 2011, s. 15], teorie rynku pracy dostarczają co najmniej pięć podstawowych argumentów na rzecz przywołanej interwencji, a mianowicie: niedostateczna przejrzystość na rynku pracy, niedostosowania alokacyjne, niewystarczająca skłonność do ryzyka, dyskryminacja grup problemowych i histereza.

Niemniej jednak to właśnie w sferze walki z bezrobociem główne zadania przypisuje się polityce rynku pracy. Jej rola sprowadza się do: aktywizacji osób bezrobotnych, promocji zatrudnienia i działań osłonowych. W ramach tej polityki są stosowane zarówno pasywne, jak i aktywne jej instrumenty. Pierwsze odzwierciedlają zobowiązania państwa w stosunku do osób pozostających bez pracy. Mają one charakter obligatoryjny i nie wpływają bezpośrednio na rozmiary bezrobocia. Jego ograniczaniu bowiem służą instrumenty aktywne [Regionalne zróżnicowanie..., 2008, s. 135]. Rola tych instrumentów powinna służyć przede wszystkim: aktywizacji zawodowej osób bezrobotnych dzięki aktywnym programom rynku pracy, zmniejszeniu niedopasowań strukturalnych na rynku pracy oraz oddziaływaniu na wielkość zatrudnienia i poziom bezrobocia [Kwiatkowski, 1998, s. 9]. Zatem aktywne instrumenty polityki rynku pracy (ALMP) są ukierunkowane zwłaszcza na przygotowanie bezrobotnych do pierwszego bądź ponownego włączenia się w proces pracy, zaś pasywne (PLMP) pełnią wyłącznie funkcję osłonowo-socjalną [Kabaj, 2004, s. 148].

Ponadto aktywne programy zatrudnienia powinny być stosowane w odniesieniu do wyselekcjonowanych, znajdujących się $\mathrm{w}$ najtrudniejszym położeniu, regionalnych rynków pracy i grup największego ryzyka [Wiśniewski, 2010, s. 16]. Decydujący wpływ na skalę i strukturę wydatków Funduszu Pracy ma więc sytuacja na wojewódzkim rynku pracy, a w szczególności poziom bezrobocia oraz liczba osób uprawnionych do pobierania zasiłków i świadczeń finansowanych z Funduszu Pracy. Dlatego też wysokość limitowanych środków z funduszu na finansowanie programów na rzecz: promocji 
zatrudnienia, łagodzenia skutków bezrobocia i aktywizacji bezrobotnych jest ustalana corocznie na podstawie wzoru algorytmicznego. Mimo to należy zaznaczyć, że środki na zasiłki dla bezrobotnych nie wchodzą w limity finansowe na działania związane $z$ łagodzeniem skutków bezrobocia i są uzależnione od liczby bezrobotnych aktualnej w danym okresie. Powiaty bowiem otrzymują środki na działania osłonowe (zasiłki) doraźnie według faktycznych potrzeb.

Jednakże wysokie koszty realizacji polityki rynku pracy sprawiają, że od lat staje się ona przedmiotem ostrej krytyki, która często podważa sens jej stosowania [Wiśniewski, 2002, s. 326]. Chodzi bowiem o to, aby środki wydatkowane z Funduszu Pracy rzeczywiście służyły przeciwdziałaniu bezrobociu i tworzeniu miejsc pracy w Polsce. Historia alokacji środków przeznaczonych na aktywne i pasywne programy rynku pracy pokazuje, że dopiero w ostatnich latach nastapiła ewolucja podejścia do realizowanej polityki rynku pracy [Cicha, 2012, s. 22]. Tym samym zwiększenie wydatków na programy aktywnego przeciwdziałania bezrobociu wywołało w Polsce publiczna dyskusję nad efektywnością tych instrumentów. Aktywna polityka rynku pracy, jako działalność angażująca środki publiczne, powinna podlegać systematycznej ewaluacji, której celem jest ocena jakości i wartości tej interwencji [Maksim, Wojdyło-Preisner, 2011, s. 55].

W zwiazku z tym celem niniejszego opracowania jest przestrzenna analiza efektywności instrumentów stosowanych w ramach aktywnej polityki rynku pracy oraz poziomu i struktury środków z Funduszu Pracy przeznaczonych na ich finansowanie. Założeniem metodologicznym jest teza, iż zarówno finansowanie, jak i efektywność aktywnych polityk rynku pracy w dużej mierze są zróżnicowane przestrzennie i uzależnione od poziomu rozwoju gospodarczego regionu oraz sytuacji na regionalnym rynku pracy.

Problem regionalnego zróżnicowania finansowania, jak i efektywności instrumentów aktywnej polityki rynku pracy jest aktualny i ważny nie tylko z punktu widzenia równoważenia rynku pracy, ale również alokacji środków publicznych przeznaczonych na przeciwdziałanie bezrobociu. Efektywność podejmowanych działań aktywizujących, analizowana przy wykorzystaniu istniejaccych wskaźników, powinna bowiem pomóc w podejmowaniu decyzji o kierowaniu tych środków finansowych do regionów czy grup społecznych szczególnie narażonych na wykluczenie społeczne w aspekcie rynku pracy. Natomiast w ujęciu regionalnych rynków pracy może stanowić ważną informację w stymulowaniu wzrostu gospodarczego oraz zmniejszaniu dysproporcji w rozwoju regionalnym.

\section{Metodyka badań}

Różnorodność efektów aktywnej polityki rynku pracy sprawia, że sukces programu może być rozmaicie definiowany. Wybór miar efektywności aktywnych form zależy od przyjętej w ewaluacji perspektywy: makro- i/lub mikroekonomicznej [Maksim, 2010, s. 113]. Przyjęte w artykule podejście mikroekonomiczne polega na określeniu wpływu uczestnictwa osób w aktywnych programach rynku pracy na ich pozycję na rynku po 
zakończeniu programu oraz koszty tej interwencji. Przedmiotem analizy jest zatem efektywność zatrudnieniowa i kosztowa wybranych aktywnych form.

Pod względem efektywności zatrudnieniowej jest istotny zarówno pomiar jej efektu brutto, jak i netto. Efekt brutto obrazuje jedynie zmiany zaobserwowane po podjęciu określonej interwencji, które równie dobrze mogą być determinowane innymi czynnikami niezależnymi od prowadzonych działań aktywizacyjnych. Z kolei efekt netto odzwierciedla faktyczny wpływ określonego programu na sytuację po jego zakończeniu, czyli informuje, czy i w jakim stopniu wzrost zatrudnienia, czy podjęcie przez bezrobotnego pracy nastapily wskutek zastosowania konkretnych działań aktywnych [Efektywnośćpolityki..., 2011, s. 55].

Z uwagi na skomplikowaną procedurę badawczą mierzenia efektu netto oraz brak bezpośredniego dostępu do danych jednostkowych agregowanych przez urzędy pracy (ochrona danych osobowych) autorka postanowiła ograniczyć się do analizy systemu monitorowania programów rynku pracy stosowanego obecnie w publicznych służbach zatrudnienia (PSZ), w ramach którego są mierzone i oceniane efekty brutto podstawowych form aktywizacji przy wykorzystaniu:

- $\quad$ stopy ponownego zatrudnienia - obliczonej jako stosunek liczby osób, które po zakończeniu udziału w danym roku, w określonej formie aktywizacji uzyskały w okresie do trzech miesięcy zatrudnienie, tj. wyrejestrowały się z powiatowego urzędu pracy lub jeżeli w okresie do trzech miesięcy od czasu zakończenia udziału w programach nie zarejestrowały się w powiatowym urzędzie pracy, do liczby osób, które w danym roku zakończyły udział w danej formie aktywizacji;

- $\quad$ kosztu ponownego zatrudnienia - obliczonego w wyniku podzielenia kwoty poniesionych wydatków w danym roku na daną formę aktywizacji przez liczbę osób, które po zakończeniu udziału w tym roku w danej formie aktywizacji uzyskały w okresie do trzech miesięcy zatrudnienie [Efektywność podstawouych form aktywizacji..., 2013].

Opracowanie prezentuje więc przestrzenną analizę stosowania, finansowania i efektywności podstawowych instrumentów aktywnej polityki rynku pracy. Ukazanie ewolucji poziomu i struktury wydatków z Funduszu Pracy na finansowanie tej polityki w Polsce w układzie regionalnym i wzbogaconym o porównania międzynarodowe może stanowić swojego rodzaju repozytorium wiedzy z tego obszaru. Natomiast empiryczna analiza efektywności stosowanych narzędzi, wykonana za pomocą zdefiniowanych i obliczonych wcześniej wskaźników względnych efektywności przez PSZ (efekt brutto) oraz za pomocą metody propensity score matching (efekt netto) ${ }^{2}$, ma za zadanie ukazać nie tylko zróżnicowanie tej efektywności w zależności od stosowanego instrumentu, ale przede wszystkim w układzie regionalnym. Powszechnie również wiadomo, iż stosowana przez PSZ metodologia analizy efektywności nie jest dostosowana do obecnych rea-

2 Zespół pod kierownictwem Profesora Z. Wiśniewskiego podją się realizacji szerokiego projektu, którego głównym celem było opracowanie metodologii badania efektywności aktywnych form przeciwdziałania bezrobociu. Analiza efektywności netto aktywnych polityk rynku pracy została przeprowadzona m.in. za pomocą metody propensity score matching. Więcej w: [Efektywnośćpolityki rynku pracy..., 2011]. 
liów funkcjonowania rynku pracy. Dlatego też porównanie w ten sposób obliczonych efektów brutto poszczególnych instrumentów aktywizujących z efektami netto opracowanymi przez zespół Wiśniewskiego ma na celu ukazanie: po pierwsze, różnic w pomiarze skuteczności stosowanych instrumentów w zakresie ich oddziaływania na zatrudnienie w zależności od metodologii, po drugie, faktycznego wpływu konkretnego, aktywnego działania na wzrost zatrudnienia w gospodarce.

\section{Finansowanie aktywnej polityki rynku pracy w Polsce}

Znaczna część działań w zakresie polityki rynku pracy jest finansowana z Funduszu Pracy utworzonego w 1990 roku jako fundusz celowy. Głównym jego celem jest łagodzenie skutków pozostawania bez pracy oraz finansowanie programów na rzecz: promocji zatrudnienia, łagodzenia skutków bezrobocia i aktywizacji zawodowej.

Wydatki na finansowanie instrumentów polityki rynku pracy w 22-letnim okresie funkcjonowaniu funduszu (lata 1990-2012) wyniosły ponad $152 \mathrm{mld} \mathrm{zł}{ }^{3}$, z czego znaczną część tej kwoty pochłonęły zasiłki i świadczenia dla osób bezrobotnych $(66,6 \%$, tj. 101 mld zł). W efekcie nakłady na aktywne formy przeciwdziałania bezrobociu w Polsce były stosunkowo skromne, gdyż stanowiły zaledwie około 29\% (44,1 mld zł) wszystkich środków, a to istotnie ograniczało skuteczność ich działania. Dopiero w ostatnich latach ewolucja w podejściu do realizowanej polityki rynku pracy spowodowała stopniowe odchodzenie od działań osłonowych na rzecz wzmacniania instrumentów aktywizacji zawodowej osób bezrobotnych [Cicha, 2010, s. 127-128]. Obserwowane są zmiany nie tylko w poziomie, ale i samej strukturze wydatków z Funduszu Pracy. Wyłania się bowiem pewien trend w polityce rynku pracy ukierunkowany na wspieranie przedsiębiorczości i tworzenie trwałych miejsc pracy, a także wspieranie pracodawców, którzy przechodzą przejściowe trudności ekonomiczne. Głównie jest on widoczny w zwiększonych nakładach finansowych, jak i samym zainteresowaniu beneficjentów uczestnictwem w poszczególnych formach aktywizacji [Cicha, 2012, s. 23].

Mimo ogólnego wzrostu wydatków na politykę rynku pracy w Polsce, ciagle należą one do najniższych w porównaniu z innymi krajami Unii Europejskiej. Z najnowszych, dostępnych danych porównawczych wynika, że w 2011 roku kraje UE-15 wydatkowały na aktywne i pasywne formy przeciwdziałania bezrobociu około $2 \%$ PKB, a średnia dla UE-28 wynosiła 1,9\% PKB. W Polsce udział ten kształtował się na poziomie $0,72 \%$ (tabela 1.). Jak zauważa Wiśniewski [Wiśniewski, 2010, s. 27], relacja ta jest zbliżona do poziomu przed wstapieniem do Unii Europejskiej.

Ponadto udział wydatków na politykę rynku pracy w PKB w Polsce ma od 2005 roku tendencję malejąca i zmniejszył się do 2011 roku o 0,56 punktu procentowego. Wyjątek stanowiły lata 2009-2010, kiedy to istotny przyrost tych wydatków był uza-

\footnotetext{
${ }^{3}$ Są to obliczenia własne na podstawie danych: [Informacja o aktywnych formach przeciwd dia ciu i wykoraystaniu środków finansowych, 2006; Praychody i wydatki ₹. Funduszu Pracy w latach 2005 - 2012]..
} 
sadniony spowolnieniem gospodarczym i ograniczonym popytem na pracę. Jednak dobre wyniki gospodarcze w 2010 roku oraz ograniczenia wynikające z procedur oszczędnościowych nie uzasadniały utrzymania wysokich wydatków w kolejnych latach. Co więcej, nastąpił wyraźny spadek wydatków na pasywne programy rynku pracy (tabela 1.) spowodowany zmniejszeniem liczby osób uprawnionych do zasiłku dla osób bezrobotnych.

TABELA 1.

\section{Wydatki na politykę rynku pracy jako \% PKB w Unii Europejskiej i Polsce w latach 2005-2011}

\begin{tabular}{|c|c|c|c|c|c|c|c|c|}
\hline Kategorie & Kraje & 2005 & 2006 & 2007 & 2008 & 2009 & 2010 & 2011 \\
\hline \multirow{3}{*}{$\begin{array}{l}\text { Ogółem - ka- } \\
\text { tegorie: } 1 .-9 .\end{array}$} & UE-15 & 2,08 & 1,89 & 1,67 & 1,70 & 2,27 & 2,26 & 2,00 \\
\hline & UE-28 & 1,99 & 1,82 & 1,60 & 1,61 & 2,16 & 2,15 & 1,89 \\
\hline & Polska & 1,28 & 1,16 & 1,01 & 0,90 & 0,96 & 1,04 & 0,72 \\
\hline \multirow{3}{*}{$\begin{array}{l}\text { Pośrednictwo } \\
\text { pracy i doradz- } \\
\text { two zawodowe } \\
\text { - kategoria } 1 \text {. }\end{array}$} & UE-15 & 0,23 & 0,21 & 0,20 & 0,20 & 0,25 & 0,26 & 0,22 \\
\hline & UE-28 & 0,22 & 0,20 & 0,19 & 0,19 & 0,24 & 0,25 & 0,21 \\
\hline & Polska & 0,07 & 0,09 & 0,10 & 0,09 & 0,10 & 0,09 & 0,08 \\
\hline \multirow{3}{*}{$\begin{array}{l}\text { Instrumenty } \\
\text { aktywne - kate- } \\
\text { gorie: } 2 .-7 \text {. }\end{array}$} & UE-15 & 0,54 & 0,52 & 0,48 & 0,48 & 0,54 & 0,56 & 0,49 \\
\hline & UE-28 & 0,52 & 0,50 & 0,46 & 0,47 & 0,52 & 0,54 & 0,47 \\
\hline & Polska & 0,35 & 0,36 & 0,40 & 0,47 & 0,53 & 0,60 & 0,33 \\
\hline \multirow{3}{*}{$\begin{array}{l}\text { Instrumenty } \\
\text { pasywne - ka- } \\
\text { tegorie: } 8 .-9 \text {. }\end{array}$} & UE-15 & 1,32 & 1,17 & 0,99 & 1,02 & 1,47 & 1,44 & 1,28 \\
\hline & UE-28 & 1,26 & 1,12 & 0,95 & 0,96 & 1,39 & 1,36 & 1,21 \\
\hline & Polska & 0,86 & 0,71 & 0,51 & 0,35 & 0,34 & 0,34 & 0,30 \\
\hline
\end{tabular}

Źródło: opracowanie własne na podstawie danych EUROSTAT.

W większości państw unijnych dominującym trendem ostatnich lat jest zatem przechodzenie z obszaru łagodzenia skutków bezrobocia w kierunku wykorzystywania aktywnych instrumentów polityki rynku pracy. Bowiem dominacja instrumentów pasywnych wyraźnie słabnie. Mimo że w ostatnim czasie Polska poziomem nakładów na działania aktywne wprawdzie dorównuje średniej dla 28 państw Unii Europejskiej i niewiele odbiega od poziomu, jaki osiagaja kraje 15-stki (tabela 1.), to wydatki te sa nadal niższe niż w niektórych krajach Unii Europejskiej. Dla porównania, w 2010 roku w Danii na ALMP przeznaczono 1,4\% PKB, w Finlandii 0,9\%, a w Polsce 0,6\% PKB. Jednak rok później, z uwagi na działania mające na celu zmniejszenie długu publicznego, udział tych środków w PKB był już znacznie niższy i wyniósł zaledwie 0,3\% PKB. W 2011 roku na aktywne formy przeciwdziałania bezrobociu wydano ponad 50\% środków mniej niż rok wcześniej (6,5 mld w 2010 roku i tylko 3,1 mld w $2011 \mathrm{roku}$ ), podobnie było w 2012 roku [Kabaj, 2012, s. 2]. 
Wysokość wydatków Funduszu Pracy na aktywne programy rynku pracy, obok znaczących wahań od początku lat dziewięćdziesiątych [Cicha, 2010, s. 127-128], charakteryzuje również pewnego rodzaju procykliczność (rysunek 1.).

RYSUNEK 1.

\section{Wydatki na politykę rynku pracy a dynamika PKB w latach 1997-2012}

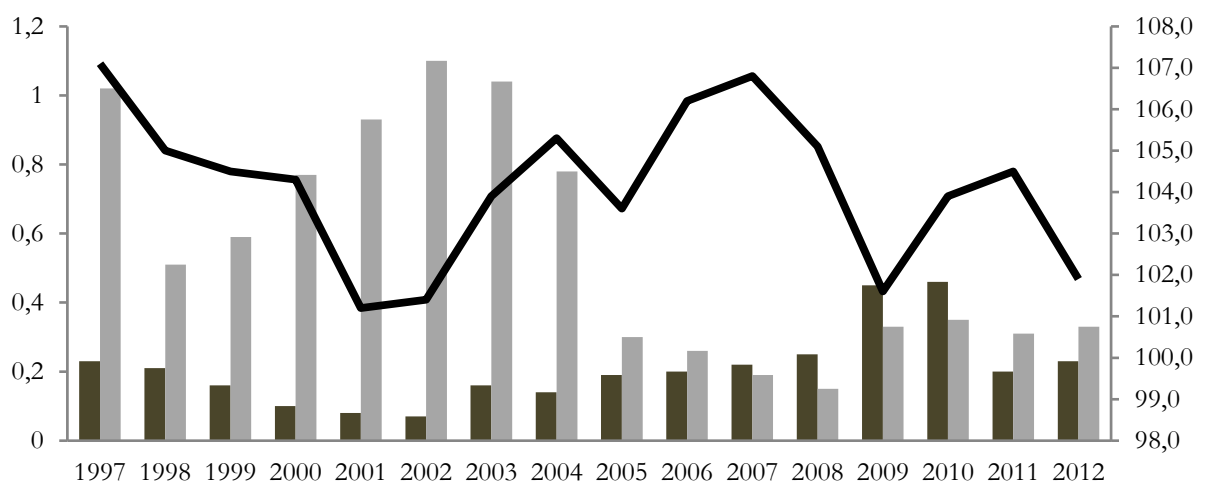

udział wydatków ALMP w PKB

udział wydatków pasywnych* w PKB

dynamika PKB

* Wydatki na zasiłki i świadczenia uwzględniaja przeniesienie od 1 sierpnia 2004 roku obsługi świadczeń przedemerytalnych i zasiłków przedemerytalnych z Funduszu Pracy do ZUS, które od 1 lutego 2009 roku powróciły do Funduszu Pracy.

Źródło: opracowanie własne na podstawie danych MPiPS i GUS.

Udział wydatków na ALMP zwiększał się w okresie szybkiego wzrostu gospodarczego i malał, gdy malała dynamika produktu. Z kolei odwrotną tendencję można zaobserwować w przypadku wydatków pasywnych, czyli zasiłków i innych świadczeń [Zatrudnienie $w$ Polsce, 2005, s. 204]. Przykładem może być fala bezrobocia pod koniec lat dziewięćdziesiątych, której wynikiem było wyraźne osłabienie działań aktywizacyjnych na rzecz szeroko zakrojonych działań osłonowych. Stopa bezrobocia na poziomie około 20\% w roku 2002 i 2003 spowodowała, że instrumenty pasywne zupełnie zdominowały wydatki na politykę rynku pracy. Na zasiłki i inne świadczenia wydatkowano bowiem ponad 80\% środków z Funduszu Pracy. Zmiana podejścia do realizowanej polityki rynku pracy nastapiła dopiero po wstapieniu Polski do Unii Europejskiej i była wynikiem włączenia się w pełnym zakresie w realizację Strategii Ližbońskiej, w szczególności zaś Europejskiej Strategii Zatrudnienia, co zresztą zaowocowało Ustawa o promocji zatrudnienia i instytucjach rynku pracy (Dz. U. z 2004 roku, Nr 99, poz. 1001). Niemniej jednak, jak pokazują ostatnie lata (2011 i 2012), w wyniku dążenia do zmniejszenia długu publicznego oraz osłabienia dynamiki PKB wydatki przewidziane w ustawie budżetowej na aktywne formy przeciwdziałania bezrobociu zostały 
ponownie zmniejszone. W tym samym czasie wysokość środków na działania osłonowe utrzymała się na mniej więcej stałym poziomie.

Zatem porównanie udziału wydatków na politykę aktywną i pasywną w kolejnych latach świadczy o wymienności obu rodzajów polityk. Priorytetowa pozycja działań o charakterze osłonowym i pasywnym powoduje, że w sytuacji ograniczeń budżetowych wypierają one działania służące aktywizacji [Osiecka-Chojnacka, 2006, s. 17]. Odróżnia to polską politykę rynku pracy od pozostałych państw OECD, gdzie wydatki na ALMP kształtują się stabilnie w całym cyklu, a ich udział w PKB nie podlega istotnym wahaniom [Nagel, Smandek, 2010, s. 154; Zatrudnienie w Polsce, 2005, s. 204].

Natomiast zróżnicowanie poziomu środków przeznaczonych na realizację aktywnej polityki rynku pracy w poszczególnych województwach zależy przede wszystkim od sytuacji na regionalnym rynku pracy. Zgodnie $z$ aktualnym algorytmem podziału tych środków ${ }^{4}$, udział danego województwa w wydatkach finansowanych z Funduszu Pracy jest uzależniony od: liczby zarejestrowanych bezrobotnych powyżej 50. roku życia, poniżej 25. roku życia, stopy i poziomu bezrobocia oraz płynności rynku pracy (tabela 2.).

W 2012 roku na realizację programów na rzecz promocji zatrudnienia przeznaczono kwotę ogółem dla wszystkich regionów w wysokości 2 459,4 mln zł. Największa część środków została wydatkowana w województwach: mazowieckim (11\%), śląskim (8,9\%) oraz podkarpackim $(7,9 \%)$. Z kolei najmniejszy udział w wydatkach miały województwa: opolskie $(2,7 \%)$ i lubuskie $(2,9 \%)$. Naturalnie podział ten był odzwierciedleniem terytorialnego zróżnicowania poziomu bezrobocia wynikającego głównie z wielkości populacji danego regionu, ale także nierównomiernego rozwoju społeczno-gospodarczego. Województwa, które dysponowały największą pulą środków, odnotowały bowiem największy udział bezrobotnych w ogóle bezrobotnych w kraju, mimo że stopa bezrobocia wcale nie należała do najwyższych w tych regionach. Ponadto w województwie mazowieckim i śląskim udział osób bezrobotnych powyżej 50. roku życia w ogóle bezrobotnych był znacznie powyżej średniej dla kraju i wyniósł kolejno: 24,2\% i 23,7\%. Tymczasem w podkarpackim co czwarta osoba bezrobotna miała poniżej 25 lat.

\footnotetext{
${ }^{4}$ Sposób ustalania kwot przekazywanych jednostkom samorządu terytorialnego określa Rozporzqdzenie Rady Ministrów z dnia 17 lipca 2009 roku w sprawie algorytmu ustalania kwot środkón Funduszu Pracy na finansowanie zadań w województwie.
} 
TABELA 2. Wydatki na aktywne programy rynku pracy (2012 rok) oraz wskaźniki rynku pracy (2011 rok) w ujęciu regionalnym

\begin{tabular}{|c|c|c|c|c|c|c|c|c|c|}
\hline \multirow[b]{2}{*}{ Województwo } & \multicolumn{2}{|c|}{$\begin{array}{l}\text { Wydatki na } \\
\text { aktywne pro- } \\
\text { gramy }\end{array}$} & \multicolumn{6}{|c|}{$\begin{array}{l}\text { Wskaźniki rynku pracy w } 2011 \text { roku } \\
\text { (w \%) }\end{array}$} & \multirow{2}{*}{ 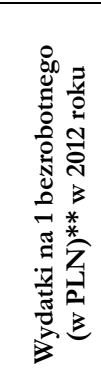 } \\
\hline & $\begin{array}{l}\widehat{E} \\
\text { है } \\
\text { 运 }\end{array}$ & $\begin{array}{l}\stackrel{8}{\circ} \\
B\end{array}$ & 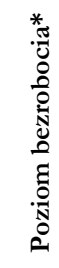 & 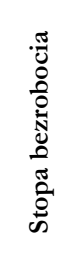 & 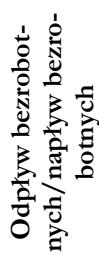 & 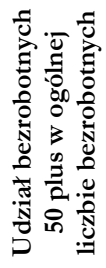 & 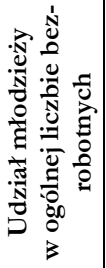 & 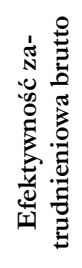 & \\
\hline Polska & 2459 & 100 & 100 & 12,5 & 0,99 & 22,3 & 21,0 & 55,7 & 1201,2 \\
\hline dolnośląskie & 180,1 & 7,3 & 7,2 & 12,4 & 1,03 & 28,1 & 16,7 & 57,0 & 1202,2 \\
\hline $\begin{array}{l}\text { kujawsko-pomor- } \\
\text { skie }\end{array}$ & 185,9 & 7,6 & 7,0 & 17,0 & 0,99 & 20,0 & 21,8 & 55,4 & 1302,5 \\
\hline lubelskie & 145,9 & 5,9 & 6,2 & 13,2 & 0,98 & 18,0 & 23,6 & 56,2 & 1164,8 \\
\hline lubuskie & 71,9 & 2,9 & 3,0 & 15,4 & 1,00 & 24,1 & 19,6 & 68,0 & 1199,3 \\
\hline łódzkie & 186,5 & 7,6 & 7,0 & 12,9 & 0,96 & 26,0 & 18,5 & 60,3 & 1273,7 \\
\hline małopolskie & 169,3 & 6,9 & 7,3 & 10,5 & 0,98 & 18,1 & 26,2 & 54,7 & 1112,9 \\
\hline mazowieckie & 272,6 & 11,0 & 12,4 & 9,8 & 0,97 & 24,2 & 19,1 & 44,7 & 1046,8 \\
\hline opolskie & 66,1 & 2,7 & 2,4 & 13,3 & 1,01 & 25,8 & 19,9 & 50,5 & 1324,7 \\
\hline podkarpackie & 194,1 & 7,9 & 7,4 & 15,5 & 0,97 & 16,8 & 23,8 & 54,9 & 1323,6 \\
\hline podlaskie & 83,0 & 3,4 & 3,3 & 14,1 & 0,97 & 23,0 & 22,4 & 55,9 & 1243,8 \\
\hline pomorskie & 127,5 & 5,2 & 5,4 & 12,5 & 0,99 & 22,0 & 22,1 & 62,1 & 1164,4 \\
\hline śląskie & 212,3 & 8,6 & 9,4 & 10,2 & 0,98 & 23,7 & 18,5 & 54,6 & 1079,0 \\
\hline świętokrzyskie & 118,9 & 4,8 & 4,2 & 15,2 & 0,99 & 20,1 & 21,9 & 53,7 & 1419,3 \\
\hline $\begin{array}{l}\text { warmińsko-mazur- } \\
\text { skie }\end{array}$ & 143,9 & 5,9 & 5,4 & 20,2 & 0,99 & 21,3 & 21,4 & 48,1 & 1334,0 \\
\hline wielkopolskie & 165,9 & 6,7 & 6,8 & 9,1 & 1,00 & 19,7 & 24,2 & 66,3 & 1177,5 \\
\hline $\begin{array}{l}\text { zachodniopomor- } \\
\text { skie }\end{array}$ & 135,7 & 5,5 & 5,5 & 17,6 & 1,00 & 26,4 & 17,7 & 55,4 & 1247,5 \\
\hline
\end{tabular}

* Poziom bezrobocia mierzony udziałem bezrobotnych danego województwa w ogóle bezrobotnych w kraju.

** Wydatki na aktywne programy rynku pracy w przeliczeniu na średnią liczbę osób bezrobotnych.

Źródło: opracowanie własne na podstawie danych: [Efektywnosíc podstawowych form...; Terytorialne zróżnicowanie ...].

Mimo ogólnego przekonania, że sytuacja na wyżej wymienionych rynkach pracy nie należy do najtrudniejszych w kraju oraz względnie niskiej efektywności zatrudnieniowej wydatkowanych w nich środków - poniżej średniej dla kraju, nasuwa się watpliwość, dlaczego to te regiony otrzymały największe fundusze na aktywizację osób bezrobotnych. Jednak w ogólnym rozliczeniu, to w tych województwach na aktywne progra- 
my rynku pracy w przeliczeniu na 1 bezrobotnego wydatkowano najniższą kwotę, gdyż nieco ponad 1000 zł. Relatywnie najwięcej wydano w województwach Polski Wschodniej (od 1164 zł w lubelskim do 1419 w świętokrzyskim). To właśnie na tych regionalnych rynkach pracy występuja poważne trudności $\mathrm{w}$ znalezieniu zatrudnienia, a stopa bezrobocia kształtuje się na względnie wysokim poziomie w porównaniu z resztą kraju.

\section{Regionalne zróżnicowanie efektywności aktywnych programów rynku pracy w Polsce}

Wysokość i struktura dochodów oraz wydatków z Funduszu Pracy zależy przede wszystkim od sytuacji na rynku pracy. Z kolei zakres stosowania poszczególnych narzędzi aktywizujących w znacznym stopniu powinien być uzależniony od ich skuteczności. Istotnym miernikiem rozwoju aktywnych polityk rynku pracy jest bowiem ich efektywność. Analiza tej efektywności dotyczy możliwości uzyskania zatrudnienia (efektywność zatrudnieniowa) przez bezrobotnego oraz ma wymiar finansowy (efektywność kosztowa/ekonomiczna).

Poziom efektywności jest zróżnicowany zarówno pod względem poszczególnych form aktywizujących, jak i przestrzennie. Regionalne ujęcie efektów stosowanych form aktywizujących ilustruje tabela 3.

Wskaźniki efektywności aktywnych form zatrudnienia w ujęciu regionalnym potwierdzają niejednolity stopień rozwoju i sytuacji na regionalnych rynkach pracy. Skala tego zróżnicowania jest szczególnie widoczna w przypadku stopy ponownego zatrudnienia i sięga 17 punktów procentowych. Największą średnią efektywność zatrudnieniową odnotowano w województwie wielkopolskim - 69,7\%, z kolei najniższą w opolskim $(52,7 \%)$ i warmińsko-mazurskim $(52,8 \%)$. W okresie trzech miesięcy od zakończenia wybranego aktywnego programu pracę znalazła w zasadzie co druga osoba aktywizowana. Efektywność w skali kraju kształtowała się bowiem na poziomie 60,9\%. Natomiast średni koszt zatrudnienia jednego bezrobotnego wynosił 10,7 tys. zł. Najwięcej na aktywizację jednej osoby wydatkowano w województwie mazowieckim - 13,7 tys. zł, a najmniej w lubuskiem - zaledwie 7,7 tys. zł.

Regionalne zróżnicowanie poziomu rozwoju społeczno-gospodarczego, a tym samym sytuacji na rynku pracy, związane ponadto z zaszłościami historycznymi, wydaje się również mieć wpływ na skuteczność podejmowanych działań aktywizacyjnych. Najmniej efektywne pod względem zatrudnienia były bowiem województwa Polski PółnocnoZachodniej. Dokonane w nich przekształcenia własnościowe przyczyniły się do tego, że efekt wzrostu gospodarczego jest mniej widoczny, a polityka rynku pracy mało skuteczna. Brak rozwiniętych, pozarolniczych działów gospodarki i niska chłonność rynków powodują że kreacja miejsc pracy w tych regionach jest trudna, a atrakcyjność inwestycyjna niewielka [Reichelt, 2007, s. 162]. Z kolei czołowe miejsce w strukturze polskiej gospodarki zajmuje region o tradycji wielosektorowej - Wielkopolska z otwartym na współpracę gospodarczą i handlową Poznaniem. Dobrze rozwinięta gospodarka, organi- 
zacja pracy oraz wspomniana wielosektorowość oddziałują na wysoką efektywność prowadzonych działań w zakresie aktywizacji bezrobotnych.

TABELA 3.

Efektywność aktywnych programów rynku pracy w 2012 roku - ujęcie regionalne

\begin{tabular}{|c|c|c|c|c|c|c|c|c|c|c|c|c|}
\hline \multirow[t]{2}{*}{ Województwo } & \multicolumn{2}{|c|}{ Ogółem } & \multicolumn{2}{|c|}{ Staże } & \multicolumn{2}{|c|}{ Szkolenia } & \multicolumn{2}{|c|}{$\begin{array}{c}\text { Prace in- } \\
\text { terwencyjne }\end{array}$} & \multicolumn{2}{|c|}{$\begin{array}{c}\text { Roboty } \\
\text { publiczne }\end{array}$} & \multicolumn{2}{|c|}{ Dotacje } \\
\hline & $\mathrm{A}$ & $\mathrm{B}$ & $\mathrm{A}$ & $\mathrm{B}$ & A & $\mathrm{B}$ & $\mathrm{A}$ & B & $\mathrm{A}$ & $\mathrm{B}$ & A & $\mathrm{C}$ \\
\hline Polska & 60,9 & 10,7 & 60,9 & 10,4 & 42,5 & 5495 & 74,4 & 6626 & 57,3 & 10,2 & 100 & 17,4 \\
\hline dolnośląskie & 64,6 & 10,8 & 66,9 & 9,6 & 43,0 & 7074 & 72,9 & 7026 & 57,9 & 8,8 & 100 & 16,7 \\
\hline $\begin{array}{l}\text { kujawsko- } \\
\text { pomorskie }\end{array}$ & 58,4 & 10,5 & 66,3 & 10,5 & 42,4 & 4505 & 84,8 & 7312 & 57,1 & 10,0 & 100 & 18,7 \\
\hline lubelskie & 64,0 & 11,0 & 62,2 & 9,5 & 39,7 & 5830 & 78,5 & 5548 & 53,4 & 10,2 & 100 & 17,9 \\
\hline lubuskie & 60,0 & 7,7 & 54,7 & 9,0 & 43,0 & 5318 & 68,2 & 5887 & 58,8 & 9,2 & 100 & 16,4 \\
\hline łódzkie & 62,8 & 11,6 & 61,5 & 11,3 & 36,8 & 5432 & 78,9 & 5504 & 74,6 & 8,2 & 100 & 18,3 \\
\hline małopolskie & 60,1 & 10,8 & 55,4 & 11,1 & 43,9 & 4789 & 75,9 & 6975 & 45,7 & 14,4 & 100 & 15,9 \\
\hline mazowieckie & 55,7 & 13,7 & 50,5 & 13,8 & 35,1 & 7955 & 64,5 & 9513 & 46,0 & 15,7 & 100 & 18,5 \\
\hline opolskie & 52,7 & 10,2 & 61,9 & 10,6 & 44,0 & 5426 & 81,9 & 8395 & 50,6 & 9,5 & 100 & 18,3 \\
\hline podkarpackie & 63,1 & 11,3 & 60,0 & 10,4 & 37,8 & 7294 & 78,7 & 6813 & 55,0 & 10,2 & 100 & 16,8 \\
\hline podlaskie & 65,9 & 10,4 & 67,1 & 9,5 & 46,2 & 4845 & 77,1 & 5287 & 54,2 & 13,0 & 100 & 18,2 \\
\hline pomorskie & 64,0 & 9,0 & 59,0 & 10,4 & 52,1 & 4509 & 70,6 & 6224 & 56,2 & 8,5 & 100 & 17,9 \\
\hline śląskie & 58,9 & 10,6 & 59,8 & 9,5 & 40,3 & 5777 & 78,8 & 6127 & 66,1 & 10,8 & 100 & 17,6 \\
\hline świętokrzyskie & 61,5 & 10,7 & 57,6 & 10,5 & 35,9 & 5418 & 80,6 & 4745 & 43,2 & 11,3 & 100 & 16,8 \\
\hline $\begin{array}{l}\text { warmińsko-mazur- } \\
\text { skie }\end{array}$ & 52,8 & 11,1 & 53,7 & 13,7 & 42,0 & 6069 & 66,2 & 7025 & 58,3 & 10,0 & 100 & 18,5 \\
\hline wielkopolskie & 69,7 & 9,1 & 73,0 & 7,8 & 51,0 & 3623 & 83,6 & 5307 & 64,2 & 9,4 & 100 & 15,3 \\
\hline $\begin{array}{l}\text { zachodniopomor- } \\
\text { skie }\end{array}$ & 61,5 & 10,1 & 68,7 & 9,7 & 47,0 & 5820 & 78,1 & 6663 & 64,3 & 9,0 & 100 & 18,5 \\
\hline
\end{tabular}

A) Efektywność zatrudnieniowa - stopa ponownego zatrudnienia (w \%).

B) Efektywność kosztowa - koszt ponownego zatrudnienia (szkolenia - w zł, pozostałe w tys. z1).

C - Przeciętny koszt (w tys. zł).

Źródło: opracowanie własne na podstawie: [Efektywność podstawowych form...].

Efektywność poszczególnych programów rynków pracy również była zróżnicowana. Najwyższe efekty brutto (100\%) przynosiły wydatki Funduszu Pracy na utworzenie miejsc pracy, tj. środki dla bezrobotnych na podjęcie działalności gospodarczej. Należy jednak pamiętać, że wynika to ze specyfiki uwarunkowań tej formy, określających, iż osoby, które otrzymały dotacje na rozpoczęcie działalności gospodarczej, muszą ja kontynuować przez co najmniej rok, a efektywność tej formy jest poddana ocenie po trzech miesiącach. Dlatego też efekt netto dotacji, w autorskich badaniach zespołu Wiśniewskiego, okazał się niższy i wyniósł 62 punkty procentowe. Oznacza to, że rzeczywisty wpływ tego instrumentu na sytuację zatrudnieniową osoby bezrobotnej 
jest o 62 punkty procentowe. wyższy niż w przypadku „identycznego” bezrobotnego, który tej dotacji nie otrzymał (tabela 4.).

TABELA 4.

Efektywność netto aktywnych programów rynku pracy w Polsce w 2009 roku (obliczona dla 6 wylosowanych powiatów)*

\begin{tabular}{|l|c|c|}
\hline $\begin{array}{c}\text { Aktywny program rynku } \\
\text { pracy }\end{array}$ & Efekt brutto (w\%) & $\begin{array}{c}\text { Efekt netto } \\
\text { (w punktach } \\
\text { procentowych) }\end{array}$ \\
\hline Szkolenia & 43,2 & $\mathbf{8 , 7}$ \\
Staże & 34,0 & 3,1 \\
Prace interwencyjne & 45,0 & 15,6 \\
Prace społecznie użyteczne & 11,2 & $-8,9$ \\
Roboty publiczne & 30,3 & 4,7 \\
$\begin{array}{l}\text { Dotacje na działalność go- } \\
\text { spodarcza }\end{array}$ & 100 & $\mathbf{6 2 , 6}$ \\
\hline
\end{tabular}

* Analiza i ocena efektywności netto aktywnych polityk rynku pracy stosowanych w Polsce w 2009 roku została przeprowadzona w sześciu powiatach, które zostały wybrane w sposób losowy z poszczególnych grup powiatów reprezentujących najbardziej zbliżony typ gospodarki i stan na rynku pracy.

Źródło: [Wiśniewski, Zawadzki, 2011].

Kolejnym, korzystnym pod względem zatrudnienia, instrumentem są prace interwencyjne ze stopa ponownego zatrudnienia na poziomie od 66,2\% w województwie warmińsko-mazurskim do 84,8\% w kujawsko-pomorskim. Faktyczny wpływ tej formy aktywizacji (efekt netto) na zatrudnienie został określony na poziomie 15,6 punktów procentowych. Jednak zatrudnienie w ramach tych prac daje pracodawcom, poza korzyściami finansowymi, możliwość poznania przydatności pracownika na danym stanowisku, natomiast bezrobotnemu - po okresowym, subsydiowanym zatrudnieniu - zdobycie stałej pracy.

Najbardziej kosztowne i jedne z najmniej efektywnych pod względem zatrudnienia okazały się roboty publiczne. Koszt ponownego zatrudnienia wahał się w przedziale od 8 do 14,5 tys. zł, a efektywność zatrudnieniowa od 43,2\% w województwie świętokrzyskim do 74,6\% w łódzkim. Ich stosowanie jest tłumaczone głównie faktem, iż podjęcie nawet czasowej pracy zachęca do dalszych poszukiwań i pozwala bezrobotnym uaktywnić się zawodowo.

Z kolei najmniej kosztowne, ale niestety mało efektywne zatrudnieniowo okazały się szkolenia. Stopa ponownego zatrudnienia w skali kraju wyniosła zaledwie 42,5\%, a koszt aktywizacji około 5,5 tys. zł. Niemniej jednak rola szkoleń w dostosowaniu struktury zawodowej bezrobotnych do potrzeb lokalnego rynku pracy i wymogów pracodawców jest niezwykle istotna, szczególnie w dobie bezrobocia strukturalnego. Ponadto szkolenia są strategiczne w warunkach realizowania gospodarki opartej na wiedzy, w której bardzo duże znaczenie mają wysokie kwalifikacje [Dolny, Maksim, 2010, s. 53]. 


\section{Podsumowanie}

W warunkach wysokiego i uporczywego bezrobocia określenie roli aktywnej polityki rynku pracy staje się szczególnie istotne, gdyż to jej właśnie przypisuje się działania, które maja za zadanie poprawę funkcjonowania rynku pracy, głównie przez przyporządkowywanie osób bezrobotnych do oferowanych miejsc pracy lub zwiększanie ich szans na zatrudnienie. Generalnie, to instrumenty tej polityki powinny przyczyniać się w sposób pośredni lub bezpośredni do tworzenia miejsc pracy oraz zwiększać zdolności do zatrudnienia bezrobotnych znajdujących się w trudnej sytuacji na rynku pracy.

Jednak skuteczność aktywnej polityki rynku pracy realizowanej w Polsce zależy przede wszystkim od poziomu środków przeznaczanych na aktywne programy rynku pracy oraz efektywności stosowanych instrumentów. Wyraźna zmiana „filozofii wsparcia" w ramach polityki rynku pracy po wstapieniu Polski do Unii Europejskiej, objawiająca się ewolucją zarówno w poziomie, jak i samej strukturze środków przeznaczanych na aktywne programy rynku pracy, rozpoczęła publiczną dyskusję nad ich efektywnością i celowością finansowania.

Mimo znacznych wahań w poziomie wydatków na aktywne programy rynku pracy w ostatnich latach i ich wyraźnej procykliczności, Polska wpisuje się w dominujący w Unii Europejskiej trend przechodzenia z obszaru łagodzenia skutków bezrobocia w kierunku wykorzystywania aktywnych instrumentów polityki rynku pracy. Należy jednak pamiętać, że wysokość środków przeznaczonych na aktywizację osób bezrobotnych, kierowana do poszczególnych województw Polski, jest ściśle związana z sytuacją jaka ma miejsce na regionalnych rynkach pracy. Sama efektywność ich wydatkowania również pozostaje zróżnicowana przestrzennie.

Wskaźniki efektywności zatrudnieniowej potwierdzają bowiem niejednolity stopień rozwoju i niejednorodna sytuację na regionalnych rynkach pracy. Różnica w stopie ponownego zatrudnienia sięga 17 punktów procentowych. Najwyższą efektywność w zakresie zatrudnienia osiaga Wielkopolska. Natomiast najniższą odnotowuje się w województwach Polski Północno-Zachodniej, na co niewątpliwie wpływa specyfika i rozwój tych gospodarek oraz związana z nią możliwość kreowania nowych miejsc pracy. Po zakończeniu programu wysoką stopa ponownego zatrudnienia charakteryzowały dotacje dla osób bezrobotnych oraz prace interwencyjne. Najbardziej kosztowne i jedne z najmniej efektywnych pod tym względem okazały się roboty publiczne. Z kolei najmniej kosztowne, ale niestety mało efektywne są szkolenia.

Metody pomiaru efektywności wyżej wymienionych form aktywizacji stosowane przez PSZ zatrudnienia sa jednak, co należy podkreślić, niedoskonałe. Wiąże się to m.in. z problemem określenia stopnia ich faktycznego wpływu na zatrudnienie osoby bezrobotnej, czyli rozróżnienia efektów nominalnych i realnych oraz niesłusznym trzymiesięcznym okresem, po jakim dokonuje się pomiaru efektywności wszystkich aktywnych instrumentów. Podjęcie przez bezrobotnego pracy może być bowiem rezultatem innych czynników niż działania samego programu, jak choćby koniunktury czy cech osoby bezrobotnej. Przypisanie tego wyłącznie konkretnemu działaniu progra$\mathrm{mu}$ jest zbyt dużym uproszczeniem. Tymczasem, jak wynika z badań empirycznych, dla szkoleń i staży oraz innych form podnoszenia kwalifikacji, ze względu choćby na 
efekt zamknięcia, przy pomiarze efektywności bardziej korzystne są okresy dłuższe niż trzy miesiące.

W dalszym ciagu w Polsce brakuje zatem spójnego systemu, który pozwalałby na pogłębioną i bieżąca analizę oraz ocenę efektywności stosowanych polityk rynku pracy. System ten bowiem powinien uwzględniać nie tylko skuteczność instrumentów, ale również ich koszty. Jednak, jak dotąd, podejmowane próby opracowania i wdrożenia odpowiedniej metodologii badania ich efektywności nie powiodły się. Mimo stworzenia w Polsce jednego z pierwszych narzędzi ewaluacyjnych wykorzystujących zaawansowaną statystykę i ekonometrię w pomiarze efektywności netto oraz wypracowania szeregu rekomendacji dla wojewódzkich i powiatowych urzędów pracy w tym zakresie, dalsze etapy projektu związane $z$ wdrożeniem tego narzędzia natrafiły na trudności o charakterze metodologicznym i praktycznym. W konsekwencji w dalszym ciagu ewaluacja aktywnych polityk rynku pracy opiera się wyłącznie na pomiarze ich efektywności brutto. Naturalnie, nie ulega wątpliwości, że stosowane w ramach tych polityk instrumenty przeciwdziałaja pewnym negatywnym skutkom bezrobocia, ale czy rzeczywiście przyczyniają się do poprawy zatrudnienia i na ile trwałe są wywołane przez nie skutki? W końcu, na ile skutecznie są wydatkowane w ten sposób środki publiczne?

Należy zauważyć, iż stosowana przez PSZ ewaluacja programów publicznych, czyli aktywnych programów rynku pracy finansowanych ze środków publicznych, jest, co prawda, zagadnieniem stosunkowo nowym, lecz wymagającym wypracowania odpowiednich: metod, narzędzi i technik. Być może nawet różnych podejść w tym zakresie.

O skuteczności aktywnej polityki rynku pracy również świadczy odpowiednie jej adresowanie, czyli dopasowanie działań prewencyjnych do osób zagrożonych bezrobociem długotrwałym. Jednak wymaga to zidentyfikowania grupy osób o wysokim ryzyku pozostania długookresowo bezrobotnym, co z kolei wiąże się z potrzebą profilowania. Po nowelizacji Ustany o promocji zatrudnienia i instytucjach rynku pracy przyznanie bezrobotnym jakiejkolwiek pomocy jest więc uzależnione od przypisania im odpowiedniego profilu. To natomiast w praktyce budzi kolejne kontrowersje związane m.in. $z$, ,szufladkowaniem” tych osób, ich „etykietowaniem” oraz, jak sami zainteresowani przyznaja, koniecznością „manipulowania prawdą” w celu otrzymania lepszego profilu, który umożliwi skorzystanie z określonej pomocy, np. w formie stażu czy dotacji.

Powstaje więc pytanie, na ile nowe rozwiązania w sferze aktywizacji osób bezrobotnych będa prawidłowo adresowane i zapewnią odpowiednia jakość oraz skuteczność stosowanych instrumentów? Czy podejście bardziej indywidualne oparte na analizie sytuacji bezrobotnych $i$ ich szans na rynku pracy w połączeniu $z$ indywidualnym planem działania $z$ danym bezrobotnym będzie skutecznym instrumentem walki z bezrobociem? W tym zakresie także niezbędna okaże się ciagła ewaluacja przebiegu „świadomej interwencji”" oraz adaptacja rozwiązań do zmieniającego się popytu na pracę.

Mimo że polityka rynku pracy nie jest ,złotym środkiem” umożliwiającym przezwyciężenie problemów zatrudnieniowych, gdyż nie jest ukierunkowana na tworzenie nowych miejsc pracy [Efektywność polityki..., 2011, s. 20], to niewattpliwie uczestnictwo w programach należy traktować jako szansę na: podtrzymanie bądź powrót do 
aktywności zawodowej, zmianę lub nabycie nowych kwalifikacji, nawiązanie kontaktów z pracodawcami czy w ogóle reintegrację społeczną.

Co prawda, wykorzystywane przez PSZ mierniki efektywności stosowanych aktywnych polityk rynku pracy są obciążone ryzykiem [Zatrudnienie w Polsce, 2005, s. 197], to aktualnie stanowią one jedyna, tym samym istotna, informację o sytuacji i skuteczności podejmowanych działań aktywizujących na regionalnych rynkach pracy. Ponadto analiza regionalnych wskaźników i porównanie ich ze sobą oraz ze średnią krajową może służyć jako wyznacznik potrzeby większej pomocy danemu regionowi w formie wsparcia merytorycznego, w lepszym projektowaniu i zarządzaniu prowadzoną polityką rynku pracy [O'Leary i in. 2001, s. 116-117].

\section{Literatura}

Cicha M. 2010 Analysis of Expenditures on Labor Market Policy In Poland During the Years 1990-2008, „Olsztyn Economic Journal”, no. 5 (1/2010).

Cicha M. 2012 Realizacja programów aktywnego przeciwdziałania bezrobociu w województwie warmińsko-mazurskim w latach 2002-2009, „Polityka Społeczna”, nr 1, IPiSS, Warszawa.

Dolny E., Maksim M. 2010 Podażowo zorientowane instrumenty polityki rynku pracy, [w:] Aktywna polityka rynku pracy w kontekśsie europejskim, Z. Wiśniewski, K. Zawadzki (red.), WUP - Uniwersytet Mikołaja Kopernika w Toruniu, Toruń.

Efektywnośc podstawowych form ak.tywizacji zawodowej realizowanych w ramach programów na rzecz.promocji zatrudnienia, tagodzenia skutkón bezrobocia i aktywizacji zawodowej w 2012 roku, dokument elektroniczny, tryb dostępu: [www.mpips.gov.pl, data wejścia: 24.02.2014].

Efektywność polityki rynku pracy w Polsce 2011, Z. Wiśniewski, K. Zawadzki (red.), WUP - Uniwersytet Mikołaja Kopernika w Toruniu, Toruń.

Efektywność polityki rynku pracy w Polsce, 2011, Wiśniewski Z., Zawadzki K. (red.) WUP-UMK, Toruń.

Informacja o aktywnych formach przeciwdziatania bezrobociu $i$ wykoraystaniu środków finansowych maj 2006 r., dokument elektroniczny, tryb dostępu: [http://www.mpips.gov.pl, data wejścia: 29.01.2014].

Jeran A. 2011 Dynamika rynku pracy i rozwój regionu: województwo warmińsko-mazurskie, „Polityka Społeczna”, nr 2.

Kabaj M. 2004 Strategie i programy przeciwdriałania bezrobociu w Unii Europejskiej i w Polsce, Wydawnictwo Scholar, Warszawa.

Kabaj M. 2012 Aktywna polityka rynku pracy $i$ jej wplyw na wrost zatrudnienia, INFOS, nr 11 (125), BAS, Warszawa.

Kwiatkowski E. 1998 Teoretyczne i metodologiczne problemy aktywnej polityki państwa na rynku pracy, [w:] Przeplywy sity roboczej a efekty aktywnej polityki państwa na rynku pracy w Polsce, E. Kwiatkowski (red.), Wydawnictwo Uniwersytetu Łódzkiego, Łódź. 
Maksim M. 2010 Metody ewaluacji aktywnej polityki rynku pracy w UE, [w:] Aketywna polityka rynku pracy w kontekście europejskim, Z. Wiśniewski, K. Zawadzki (red.), WUP - Uniwersytet Mikołaja Kopernika w Toruniu, Toruń.

Maksim M., Wojdyło-Preisner M. 2011 Metodologiczne aspek.ty oceny efektywności aktywnej polityki rynku pracy, [w:] Efektywność polityki rynku pracy w Polsce, Z. Wiśniewski, K. Zawadzki (red.), WUP - Uniwersytet Mikołaja Kopernika w Toruniu, Toruń.

Nagel K., Smandek I. M. 2010 Polityka rynku pracy i źródła jej finansowania, Wydawnictwo Uniwersytetu Ekonomicznego w Katowicach, Katowice.

Nazarczuk J. M. 2013 Potencjat rozwojowy a aktywność inwestycyjna województw i podregionów Polski, Wydawnictwo Uniwersytetu Warmińsko-Mazurskiego, Olsztyn.

O’Leary Ch. J., Nesporova A., Samorodow A. 2001 Manual on Evaluation of Labour Market Policies in Transition Economies, International Labour Office, Geneva.

Organiściak-Krzykowska A. 2005 Regionalne uwarunkowania bezrobocia, Wydawnictwo Uniwersytetu Warmińsko-Mazurskiego, Olsztyn.

Osiecka-Chojnacka A. 2006 Aktywna polityka rynku pracy, Informacja BSE, nr 1250, KS Biuro Studiów i Ekspertyz, Warszawa.

Praychody $i$ wydatki z Funduszu Pracy w latach 2005 - 2012, dokument elektroniczny, tryb dostępu: [http://www.mpips.gov.pl, data wejścia: 27.02.2014].

Regionalne zróżnicowanie wykoraystania narzedzi rynku pracy a ograniczenie bezrobocia 2008, U. Kłosiewicz-Górecka (red.), IBRKK, Warszawa.

Reichelt A. 2007 Regionalne zróżnicowanie efektywności aktywnych programów rynku pracy w Polsce, „Ruch Prawniczy, Ekonomiczny i Socjologiczny”, z. 3.

Terytorialne zróżnicowanie bezrobocia w Polsce w 2011 roku, dokument elektroniczny, tryb dostępu: [www.mpips.gov.pl, data wejścia: 24.02.2014].

Wiśniewski Z. 2002 Polityka rynku pracy, [w:] Rynek pracy wobec integracji z. Uniq Europejskeq, S. Borkowska (red.), IPiSS, Warszawa.

Wiśniewski Z. 2010 Ewolucja polskiej polityki rynku pracy, [w:] Aktywna polityka rynk.u pracy w kontekśsie europejskim, Z. Wiśniewski, K. Zawadzki (red.), WUP - Uniwersytet Mikołaja Kopernika w Toruniu, Toruń.

Witkowski J. 2007 Rynek pracy w województwie tódzkim. Specyfika i uwarunkowania, ASMCentrum Badań i Analiz Rynku, Kutno.

Zatrudnienie w Polsce 2005, M. Bukowski (red.), DAiPE MPiPS, Warszawa. 